\title{
The use of legumes as a biogas substrate - potentials for saving energy and reducing greenhouse gas emissions through symbiotic nitrogen fixation
}

\author{
P. Walter Stinner ${ }^{1,2}$
}

\begin{abstract}
Background: Energy crops are of considerable importance for biogas production, especially in Germany. The main energy crops for that purpose are corn silage, grass silage, whole crop grain silage and other non-legume crops. The reason for preferring these crops is their high yield, which not only results in high yields of biogas per hectare but also in a high mitigation of greenhouse gases in the course of replacing fossil energy. This article aims to show an additional effect exerted on energy yield and mitigation of greenhouse gases by the use of legume energy crops. The symbiotic nitrogen fixation (SNF) of legumes compensates inorganic N fertilizer in conventional farms, if the digestate is applied as a fertilizer to the non-legume cash crops. The production of chemical $\mathrm{N}$ fertilizer is very energy intensive and leads to emissions of greenhouse gases from fossil energy consumption and from nitrous oxide generation. So, the creation of an effective organic fertilizer with nitrogen from biological $\mathrm{N}_{2}$ fixation is a further energy add-on effect to the reduction of greenhouse gas emissions.

Methods: For this article, data with regard to the SNF of legumes obtained in field experiments at the research station at Gladbacherhof (University of Giessen) from 2002 to 2005 were re-calculated and compared with data concerning energy need and greenhouse gas emissions in the process of producing mineral nitrogen fertilizer. In addition to the possible methane yield of these substrates, the saving in energy and greenhouse gas emissions by substituting mineral fertilizers is shown.
\end{abstract}

Results: As a result, the possible replacement of primary energy by SNF of clover grass leys is calculated to be approximately less than 6.4 MWh ha $\mathrm{M} \mathrm{a}^{-1}$. This is a yield that is reached in addition to the methane production, i.e. a possible reduction of greenhouse gas emissions through SNF per hectare of clover grass leys of more than 2 t $\mathrm{CO}_{2}$ equivalents $\mathrm{ha}^{-1} \mathrm{a}^{-1}$ can be achieved.

Conclusions: Based on these results, it can be recommended to evaluate energy crops in a more holistic way. For legumes, the effect of SNF needs to be included into the energy and greenhouse balance.

Keywords: Greenhouse gas mitigation; $\mathrm{N}_{2}$ fixation; Biogas; Fertilizer; Legumes

Correspondence: Walter.Stinner@dbfz.de

'DBFZ Deutsches Biomasseforschungszentrum, Torgauer Str. 116, 04347

Leipzig, Germany

2Justus-Liebig-Universität, Professur für organischen Landbau,

Karl-Glöckner-Str. 21C, 35394 Gießen, Germany 


\section{Background}

Using renewable energy sources like biogas can substitute fossil sources and avoid greenhouse gas emissions. Energy crops are of considerable importance for biogas production, especially in Germany [1]. The main energy crops for that purpose are corn silage, grass silage, whole crop grain silage (grain crops chopped in the dough-ripe stage for ensiling) and other non-legume crops. The reason for preferring these crops is their high dry matter yield [2], which results in high yields of biogas per hectare and in high mitigation of greenhouse gases in the process of replacing fossil energy (natural gas, crude oil, lignite and hard coal).

This article aims to show an additional influence exerted on energy yield and mitigation of greenhouse gases through the use of legume energy crops. Via anaerobic digestion, the grown energy crops are transferred into organic fertilizers. In this way, the biological $\mathrm{N}_{2}$ fixation (symbiotic nitrogen fixation (SNF)) of legumes compensates inorganic $\mathrm{N}$ fertilizer in conventional farms, if the digestate is applied as a fertilizer to the non-legume cash crops. The production of chemical $\mathrm{N}$ fertilizer is very energy intensive and leads to emissions of greenhouse gases through the utilization of fossil fuels and the generation of nitrous oxide emissions from production processes. In this way, both climate relevant emissions, caused by the use of fossil energy sources in the manufacturing of mineral fertilizer as well as by the generation of nitrous oxide emissions during the production process, could be avoided. Thus, the creation of an effective organic fertilizer with the nitrogen from the biological $\mathrm{N}_{2}$ fixation is a further energy add-on effect leading to a reduction of greenhouse gas emissions.

\section{Methods}

The data about the biological $\mathrm{N}_{2}$ fixation of legume crops for biogas substrate derived from field experiments using organic cropping systems. The cropping systems were (i) a typical crop rotation for stockless organic farming systems and (ii) a typical crop rotation for organic dairy farms. The crop rotation of the stockless organic farming systems included: 1 . clover grass (CG); 2. potatoes (Solanum tuberosum L.); 3. winter wheat (Triticum aestivum $L$.) + catch crop (CC); 4. spring peas (Pisum sativum $L).+C C$; 5 . winter wheat $(T$. aestivum $)+C C$; and 6. spring wheat (T. aestivum) with under-sown CG. The used forage mixture of the CG consisted of Trifolium pratense L. at a seed rate of $7.5 \mathrm{~kg} \mathrm{ha}^{-1}$, Medicago sativa L. at $7.5 \mathrm{~kg} \mathrm{ha}^{-1}$, Lolium perenne L. at $5 \mathrm{~kg} \mathrm{ha}^{-1}$, Phleum pratense L. at $5 \mathrm{~kg} \mathrm{ha}^{-1}$ and Festuca pratensis Huds. at $5 \mathrm{~kg} \mathrm{ha}^{-1}$. The CC mixture consisted of common vetch (Vicia sativa L.) at a seed rate of $90 \mathrm{~kg} \mathrm{ha}^{-1}$ and oil radish (Raphanus sativus L.) at $5 \mathrm{~kg} \mathrm{ha}^{-1}$ (for more details, see [3]).
The crop rotation of the organic dairy farming system included: (1 and 2) 2 years of CG, 3. winter wheat ( $T$. aestivum) + CC, 4 . corn (Zea mays L.) at $80 \%$ of the area and potatoes (S. tuberosum) at $20 \%$ of the area, 5 . winter rye (Secale cereale L.) $+C C, 6$. spring peas $(P$. sativum) + CC, 7. spelt (Triticum aestivum subsp. spelta) and 8. spring wheat (T. aestivum) with under-sown CG. The seed mixtures of the forage ley and the catch crop mixture were the same as described above (for more details, see [4]).

The experiments were carried at the research station of the University of Giessen, Gladbacherhof, from 2002 to 2005. The site is located in the Limburg Basin (latitude $50^{\circ} 24^{\prime} \mathrm{N}$, longitude $8^{\circ} 15^{\prime} \mathrm{E}$, altitude: ca. $210 \mathrm{~m}$ ). The soils are silty loams derived from loess with $\mathrm{pH}$ values of 6.6 to 6.9. They are classified as calcic luvisols with a field capacity of 330 to $370 \mathrm{~mm} \mathrm{~m}^{-1}$. The mean soil $\mathrm{C} t$ content in the $0-$ to $30-\mathrm{cm}$ layer was $1.06 \%$, and the $\mathrm{N} t$ content was $0.125 \%$ as described in [5].

The SNF of the CC was assessed by subtracting the soil borne $\mathrm{N}$ supply from the total $\mathrm{CC} \mathrm{N}$ uptake. The soil borne $\mathrm{N}$ supply to $\mathrm{CC}$ was evaluated according to the data obtained from other trials carried out at the same site using non-leguminous CC (for more details, see [5]). The SNF of the CG was estimated according to the algorithms of Stein-Bachinger et al. [6] by multiplying DM yield $\left(\mathrm{t} \mathrm{ha}^{-1}\right)$, the legume content in the CG (\%), and an estimated $\mathrm{N}$ derived from the atmosphere (Ndfa) (\%). The percentage of Ndfa depends on DM yield, legume content and the above-ground biomass management (harvested/mulched), according to the algorithms provided by the model, see [6]. For more details, see [3].

The cropping of such legume cultures for biogas production is independent of the farming system, the organics or the conventional approach. It can also be carried out in conventional farms and will result in a replacement of non-legume energy crops and inorganic nitrogen fertilizer. The data obtained for the nitrogen yield in these experiments performed in organic farming systems are therefore transferred to conventional systems as an additional $\mathrm{N}$ yield, which can replace mineral $\mathrm{N}$ fertilizer.

To calculate the savings in energy and greenhouse gases by replacing mineral fertilizer, the occurrence of ammonia losses in the fertilization with digestate, measured in the field experiment, was taken into consideration. According to the investigations of Möller and Stinner [7] in the same research project, the losses amounted to $7 \%$ of nitrogen in the case of a separate application of the liquid and solid fermentation products (see column and line 2 of Table 1). After deducting the ammonia losses, the $\mathrm{N}$ efficiency of the separated liquid digestate, rich in ammonia is estimated to be $76 \%$, whereas the $\mathrm{N}$ efficiency of the separated solid digestate 
Table 1 Nitrogen efficiency of digestate and inorganic fertilizer

\begin{tabular}{|c|c|c|c|c|c|}
\hline Fertilizer type & $\begin{array}{c}\text { Ammonia losses } \\
\text { after spreading } \\
(\% \text { of total } N) \\
\end{array}$ & $\begin{array}{c}\text { Ammonia content } \\
\text { before spreading } \\
(\% \text { of } N t)\end{array}$ & $\begin{array}{c}\text { Effective ammonia } \\
\text { content (\% of } \mathrm{N} t) \text { after } \\
\text { deducting ammonia losses }\end{array}$ & $\begin{array}{c}\text { Overall efficiency } \\
\text { (after deducing } \\
\text { ammonia losses) }\end{array}$ & $\begin{array}{l}\text { Equivalent } \\
\text { to mineral } N \\
\text { fertilizer (\%) }\end{array}$ \\
\hline Separated digestate (liquid phase) & 7 & 71 & 64 & 76 & 88 \\
\hline $\begin{array}{l}\text { Separated solid digestate (average } \\
\text { of catch crops and clover grass) }\end{array}$ & 7 & 22 & 15 & 63 & 73 \\
\hline Inorganic nitrogen (mineral fertilizer) & 0 & - & - & 86 & 1 \\
\hline
\end{tabular}

with a high content of organic nitrogen is estimated to be $63 \%$ (Table 1). The medium $\mathrm{N}$ efficiency of mineral fertilizer is taken as $86 \%$ [8]. Thus, on average, $1 \mathrm{~kg}$ of digestate $\mathrm{N}$ counts for $800 \mathrm{~g}$ of mineral fertilizer $\mathrm{N}$.

These assumptions are based on the averaged content of ammonia and organic nitrogen in the digestate. The ammonia $\mathrm{N}$ availability is equivalent to the mineral fertilizers with regard to ammonia volatilization. The longterm availability of the organic bound nitrogen from organic fertilizers amounted to $58 \%$ to $59 \%$ [8]. For mineral $\mathrm{N}$ fertilizer, the author obtained an $\mathrm{N}$ efficiency of $86 \%$ (see line four, column five in Table 1). This resulted in an equivalence factor of $80 \%$ between the mineral fertilizer and the average of the solid and liquid digestate.

The assumptions for digestate can be seen as conservative ones, when new measures of digestate fertilizing (e.g. strip tillage with an underlaying digestate depot) will be optimized and proved (for efficient cultivation options, see Hauggaard-Nielsen et al. [9]).

The values according to Nemecek and Kägi [10,11] and Nemecek and Schnetzer [12] have been used to calculate the savings in energy and greenhouse gases when replacing the mineral fertilizer nitrogen (see also [13]). In the database for life-cycle analyses of agricultural production systems, an energy consumption for common nitrogen mineral fertilizer (ammonium nitrate) of $58.2 \mathrm{MJ} \times \mathrm{kg} \mathrm{N}^{-1}$ and emissions of $6.032 \mathrm{~kg} \mathrm{CO} 2$ eq. $\mathrm{kg}$ $\mathrm{N}^{-1}$ was obtained.

\section{Results and discussion}

Table 1 in the 'Methods' section takes not only into account the ammonia losses after spreading of digestate but also the different nitrogen efficiencies of organic and inorganic fertilizers. With regard to [13] and [7], the solid-liquid separation of digestate is a good practice measure to reduce the ammonia losses after spreading of the digestate. Due to this method, the nitrogen losses in the whole process chain as well as the $\mathrm{N}$ efficiency on the field are of great importance for the results. Important causes of losses are ammonia volatilizations in the whole process chain. In both parts, in the biogas plant and in field application, these losses are strongly influenced by the technique and management used [14-20]. The field $\mathrm{N}$ efficiency also depends on a couple of further factors in addition to the kind of fertilizer, especially in the case of organic fertilizers. These factors are application technique, time and rate of application, fertilized crop and nutrient management by crop rotation and cropping methods [21-25].

The field experiment shows an average SNF of $122 \mathrm{~kg}$ $\mathrm{N}$ ha $^{-1}$ (Table 2), see also [3], for arable land with the given crop rotation. One hectare of clover grass leys as a biogas substrate can produce up to $500 \mathrm{~kg}$ of nitrogen through SNF per main year of cultivation ([13], compared with [26]). The average SNF of legume catch crop mixtures amounted to $61 \mathrm{~kg} \mathrm{~N}$ per hectare of cover cropping. These amounts are effects achieved in addition to the potential of methane production from the harvested crops. The nitrogen in the investigated ecological system was produced without restrictions in food production. It seems to be possible to transfer the results to conventional systems. In the case of the clover grass leys, the additional nitrogen harvest as well as further effects (e.g. humus balance, preceding crop effects) needs to be balanced with lower direct biomass yields compared to other substrate crops (e.g. corn silage, whole crop silage). For the humus balance, the cropping of legume forage lays (without including the digestate) generated a surplus of 600 to 800 humus equivalent units per hectare of main cropping

Table 2 Energy consumption [kWh ha ${ }^{-1}$ ] and greenhouse gases emissions [kg $\mathrm{CO}_{2}$ eq. ha ${ }^{-1}$ ] of $\mathrm{N}$ fertilizers

\begin{tabular}{|c|c|c|c|c|c|}
\hline Fertilizer type & $\begin{array}{l}\text { Non-renewable } \\
\text { energy input } \\
\text { per kg of produced } \\
\text { nitrogen }[\mathrm{kWh} / \mathrm{kg} \mathrm{N}]\end{array}$ & $\begin{array}{l}\text { Greenhouse gases } \\
\text { emissions during } \\
\text { production }[\mathrm{t} \\
\left.\mathrm{CO}_{2} \text { eq. } \mathrm{ha}^{-1}\right]\end{array}$ & $\begin{array}{l}\mathrm{N}_{2} \mathrm{O} \text { emissions after } \\
\text { application }\left[\mathrm{kg} \mathrm{CO}_{2}\right. \\
\text { eq. } \mathrm{kg}^{-1} \text { of applied } \\
\text { fertilizer] }\end{array}$ & $\begin{array}{l}\mathrm{N}_{2} \mathrm{O} \text { emissions after } \\
\text { application }\left[\mathrm{kg} \mathrm{CO}_{2}\right. \\
\text { eq. } \mathrm{kg}^{-1} \text { of inorganic } \\
\mathrm{N} \text { fertilizer equivalent] }\end{array}$ & $\begin{array}{l}\text { Sum of greenhouse gas } \\
\text { emissions }\left[\mathrm{kg} \mathrm{CO}_{2}\right. \\
\text { eq. } \mathrm{kg}^{-1} \text { of inorganic } \\
\mathrm{N} \text { fertilizer equivalent] }\end{array}$ \\
\hline $\begin{array}{l}\text { Digestate, } \mathrm{N} \text { derived } \\
\text { from } \mathrm{SNF}^{\mathrm{a}}\end{array}$ & - & - & $2.98^{\mathrm{b}}$ & 3.73 & 3.73 \\
\hline Inorganic nitrogen & 16.17 & 6.032 & $2.98^{\mathrm{b}}$ & 2.98 & 9.01 \\
\hline
\end{tabular}

${ }^{\mathrm{a}}$ Fuel and energy for biogas plant operation belongs to methane production. ${ }^{\mathrm{b}}$ According to the IPCC scheme [10,12], the $\mathrm{N}_{2} \mathrm{O}$ emissions after application are similar but due to the lower efficiency, a higher amount is needed. So, the relevant value is the emission per kg of replaced mineral fertilizer (next column). 
depending on the yield level [27]. This surplus can cover the humus needs of other crops in the crop rotation. In contrast to that, non-legume crops for energy production or other purposes (also without taking the digestate into consideration) showed a need of 560 (corn silage), 760 (sugar beet) or 280 humus equivalent units (cereals, threshed, minimum values, respectively, see also [27]). This considerable advantage of legume forage leys should be taken into account, when comparing different energy crops.

Table 2 shows the savings in non-renewable energy (fossil + nuclear) and greenhouse gas emissions per $\mathrm{kg} \mathrm{N}$ through SNF when replacing mineral fertilizer by digestate. The value for the transfer of $\mathrm{N}$ to $\mathrm{N}_{2} \mathrm{O}$ is the same for inorganic and organic fertilizers [12]. However, the $\mathrm{N}$ efficiency of the digestate is only calculated to reach $80 \%$ of the mineral fertilizers efficiency (average of liquid and solid fraction, see Table 1), i.e. a higher amount of digestate $\mathrm{N}$ for the same fertilizing effect. Due to the fact that $\mathrm{N}_{2} \mathrm{O}$ generation is calculated on the basis of the applied $\mathrm{N}$, a higher transfer of digestate nitrogen into nitrous oxide after fertilization is calculated to be 2.98: $0.8=$ 3.73, where 2.98 is the $\mathrm{N}_{2} \mathrm{O}$ emission after the application in $\mathrm{kg}$ of $\mathrm{CO}_{2}$ equivalents for both kinds of fertilizer. The divisor 0.8 derives from the equivalence factor between digestate $\mathrm{N}$ and mineral $\mathrm{N}$, as shown in the Methods. The resulting value denotes the digestate emissions of $3.73 \mathrm{~kg} \mathrm{CO}$ equivalents per $\mathrm{kg}$ of mineral $\mathrm{N}$, which is replaced by (1.25 kg of) digestate N. In this way, the results of digestate emissions are comparable to the values of mineral fertilizer.

The net savings of greenhouse gases through SNF [ $\mathrm{kg} \mathrm{CO} 2$ eq. $\mathrm{kg}^{-1}$ of inorganic $\mathrm{N}$ fertilizer replaced] are $9.01-3.73=5.28$, where 9.01 is the sum of greenhouse gas emissions (in $\mathrm{kg}$ of $\mathrm{CO}_{2}$ equivalents) per $\mathrm{kg}$ of $\mathrm{N}$ caused by mineral fertilizer and 3.73 is the greenhouse gas emissions (in $\mathrm{kg}$ of $\mathrm{CO}_{2}$ equivalents) for the replacement of $1 \mathrm{~kg}$ inorganic $\mathrm{N}$ by digestate (Table 2).
The energy for cropping and processing the clover grass is calculated as part of the methane production as well as the emissions from cropping and operating the biogas plant. This makes the values comparable with the use of other energy crops without the benefits from SNF, such like corn silage.

Table 3 shows the values of energy savings and greenhouse gases calculated for the given field data. In the case of the catch crops, the results of the field experiments did not show any differences in the dry matter yield regarding the $\mathrm{N}$ nutrition [5]. Depending on the $\mathrm{N}$ availability, only the composition of the mixture was adapted. Higher $\mathrm{N}$ availability leads to higher contents of the non-legume partner in the mixture and vice versa. This effect was often found by other authors as cited in [5] and [13]. This may be different, if other catch crops can be integrated (e.g. annual ryegrass). The nitrogen yields by SNF were strongly dependent on the nitrogen availability: as higher the nitrogen availability, the lower the SNF. This means, a strategy to optimize nitrogen harvest should be to only recognize the use of fertilizers of a wide $\mathrm{C} / \mathrm{N}$ ratio in the fertilization of legume mixtures for biogas substrate. This is evident when comparing the SNF after cereals and peas (Table 3) and furthermore when studying the results of catch crops amended with digestate (data not shown).

Depending on the different previous crops and the remaining nitrogen, the catch crops have fixed 36 to $77 \mathrm{~kg} \mathrm{~N} \mathrm{ha}^{-1}$ of nitrogen by SNF $\left(\mathrm{x}^{-}=61 \mathrm{~kg} \mathrm{~N} \mathrm{ha}^{-1}\right.$, Table 1). For most of the locations relating to catch crops, as determined by water supply and the harvest period of the previous crops, a transfer to conventional conditions is possible. To ensure a high SNF, the use of nitrogen fertilizers to legume mixtures must be avoided because high nitrogen availability leads to higher contents of non-legume partners in the mixtures and a low SNF from legumes [5,28-32].

Table 3 Savings of energy and greenhouse gases by replacing mineral nitrogen

\begin{tabular}{|c|c|c|c|c|}
\hline Element of cultivation & SNF & $\begin{array}{c}\text { Replacement } \\
\text { of mineral } \\
\text { fertilizer }\end{array}$ & $\begin{array}{c}\text { Savings of } \\
\text { energy }\left[\mathrm{kWh} \mathrm{ha} \mathrm{ha}^{-1}\right]\end{array}$ & $\begin{array}{c}\text { Savings of } \\
\text { greenhouse gases } \\
{\left[\mathrm{kg} \mathrm{CO} \mathrm{CO}_{2} \text { eq. } \mathrm{ha}^{-1}\right]}\end{array}$ \\
\hline $\begin{array}{l}\text { Clover grass leys as catch crop (CC, autumn growth } \\
\text { after harvest of spring wheat) }\end{array}$ & 65 & 52 & 841 & 275 \\
\hline Clover grass leys (year of main crop) & 498 & 398 & 6,436 & 2,101 \\
\hline CC after WW3 & 77 & 62 & 1,003 & 327 \\
\hline CC after peas & 36 & 29 & 469 & 153 \\
\hline CC after WW5 & 66 & 53 & 857 & 280 \\
\hline$\overline{\mathbf{x}} \subset C$ & 61 & 49 & 792 & 259 \\
\hline$\Sigma$ arable land (AL, 6 ha) & 730 & 584 & 9,443 & 3,084 \\
\hline$\overline{\mathbf{x}} \mathrm{AL}$ & 122 & 98 & 1,578 & 517 \\
\hline
\end{tabular}

Acronyms: $W W 3$ = winter wheat in third place of crop rotation, $W W 5=$ winter wheat in fifth place of crop rotation. 
This means that a sufficient capacity of fermentation residue storage is necessary. For high SNF, forage mixtures or catch crops with the option to be mixtures with legumes should not be regarded as an element for clearing the digestate storages anymore. Alternative adjustments in the selection and management of non-legume market crops are required. With the usual technique, the fertilization of winter grains with liquid digestate (of a narrow $\mathrm{C} / \mathrm{N}$-ratio) should be carried out under the beneficial soil conditions at the beginning of the vegetation period in early spring. Concentrating injection techniques, optionally combined with measures against nitrification, have proved to be suitable for the fertilization of such crops with liquid organic fertilizers. For instance, in the cultivation of corn, the fertilization with digestate would be possible until July, provided an appropriate equipment is applied. The cash crop for a moderate fertilization with digestate (or other organic fertilizers of a small $\mathrm{C} / \mathrm{N}$ ratio) in the second half of the year is rapeseed (Brassica napus L.) due to its high nitrogen uptake before wintertime [33]. This crop can be amended with digestate ideally before seeding in August. The amount of digestate for a reasonable fertilization strongly depends on the $\mathrm{N}$ surpluses and the straw management of the pre-crop.

In addition to the possible biogas production [34], the use of clover grass leys as a biogas substrate can reduce the primary energy consumption to more than 6.4 $\mathrm{MWh} \mathrm{ha}{ }^{-1}$ and the greenhouse gas emissions to more than $2 \mathrm{t} \mathrm{CO}_{2}$ eq. ha ${ }^{-1}$ (Table 2) in a conventional system when replacing mineral nitrogen fertilizer. Legume intercrop mixtures were able to save approximately $0.8 \mathrm{MWh} \mathrm{ha}{ }^{-1} \mathrm{a}^{-1}$ and more than $200 \mathrm{~kg} \mathrm{CO}_{2}$ equivalents ha $\mathrm{h}^{-1} \mathrm{a}^{-1}$.

At the moment, in conventional systems, the use of such legume mixtures for biogas production is almost of no significance. Corn silage and further non-legumes are the most important crops producing biogas in Germany [1] due to their high methane yields. Indeed, using grass leys as substrate crops is an interesting alternative under certain local conditions [35].

The results show additional effects exerted by legume energy crops on energy yields and greenhouse gas savings, which have not been discussed by other authors until now. The SNF, which is set up above, has led to an improvement of this crop.

Further advantages of applying legume forage leys as energy crops are the following: expansion of tight crop rotations, abatement of the risks for the corn cultivation through the corn rootworm [36-38], extended soil regeneration period, protection against erosion, lower production of nitrous oxide by the soil as compared to the use of non-legumes due to the absence of nitrogen fertilization $[7,10]$, and lower danger of nitrate leaching through soil coverage all year. The high competitive strength of clover grass leys is a measure of good weed inhibition. Considering nitrogen efficiency and the mentioned agronomic effects $[39,40]$, the economic use of clover grass leys and catch crop legumes when applying a biogas technique may be of advantage also under conventional circumstances.

Under this background, the efficiencies of different energy crops should be re-discussed and compared to the literature findings $[2,41,42]$.

\section{Conclusions}

The results show a strong underestimation of the yields of legumes as energy crops. Currently, energy crops for biogas digestion are mainly annual non-legume crops such as corn silage, whole crop grain silage (grain crops chopped in the dough-ripe stage for ensiling), etc. These crops are mainly regarded as the most effective because of their high methane production per hectare and the great replacing of fossil energy carriers. The high amount of energy saving (e.g. more than $20 \%$ of energy in addition to the methane yield of clover grass leys $[13,43]$ ) and the greenhouse gas mitigation by replacement of mineral nitrogen by symbiotic fixed nitrogen of legume crops for biogas production are remarkable, when the digestate is used to fertilize the non-legume crops. These results should be integrated in holistic evaluations of energy crops. This measure may change the relative advantages of different crops as biogas substrates.

\section{Abbreviations}

AL: arable land; CC: catch crop; ha: hectare; N: nitrogen; SNF: symbiotic nitrogen fixation.

\section{Competing interests}

The author declares that he has no competing interests.

\section{Acknowledgements}

I would like to thank the Deutsche Bundesstiftung Umwelt (DBU) for the financial support of the field experiments, Dr. Kurt Möller for creating the research concept as well as for a lot of helpful discussions and joint publications. Furthermore, I am grateful to my PhD colleague Arno Deuker for all the work done together, the colleagues from the chair of organic agriculture including the research station as well as the colleagues of the chair of microbiology of the University of Giessen for all the support on field, in lab and in discussions of the results in the area of soil borne trace gas emissions. I would like to thank Prof. Dr. Günter Leithold for opening his research capacities for the combination of biogas and organic farming. Thanks are due to my colleagues from the DBFZ for supporting the ecoinvent database and for reading the script, in particular, to Elisa Thieme, Jaqueline Daniel-Gromke, Velina Denysenko, Eva Nebel, Katja Oemichen and Stefan Majer. And last but not least, I would like to thank Dagmar Fiedler (UFZ) for proofreading the manuscript.

\section{Dedication}

This publication is dedicated to Prof. Andreas Zehnsdorf on the occasion of his 50 th birthday.

Received: 1 July 2014 Accepted: 8 January 2015

Published online: 22 January 2015 


\section{References}

1. DBFZ (2014) Stromerzeugung aus Biomasse; (Vorhaben lla Biomasse), Zwischenbericht Juni 2014; Projektleitung: Mattes Scheftelowitz; Projektbearbeitung: Jaqueline Daniel-Gromke, Nadja Rensberg, Velina Denysenko, Konrad Hillebrand, Karin Naumann, Mattes Scheftelowitz, David Ziegler, Janet Witt (DBFZ); Michael Beil, Wiebke Beyrich (beide IWES); available: https://www.dbfz.de/web/presse/pressemitteilungen-2014/ dbfz-veroeffentlicht-monitoring-zwischenbericht-zur-stromerzeugung-ausbiomasse.htm

2. Vetter A, Eckner J, Strauß C, Nehring A (2014) Entwicklung und Optimierung von standortangepassten Anbausystemen für Energiepflanzen im Fruchtfolgeregime; Abschlussbericht zum Teilprojekt 1; (EVA II); available: http://www.eva-verbund.de/untersuchungsberichte/teilprojekte/teilprojekt1-pflanzenbau.html

3. Stinner W, Möller K, Leithold G (2008) Effects of biogas digestion of clover/ grass-leys, cover crops and crop residues on nitrogen cycle and crop yield in organic stockless farming systems. Eur J Agron 29:125-134

4. Möller K, Stinner W, Deuker A, Leithold G (2008) Effects of different manuring systems with and without biogas digestion on nitrogen cycle and crop yield in mixed organic dairy farming systems. Nutr Cycl Agroecosyst 82:209-232, doi:10.1007/s10705-008-9196-9

5. Möller K, Stinner W, Leithold G (2008) Growth, composition, biological N fixation and nutrient uptake of a leguminous cover crop mixture and the effect of their removal on field nitrogen balances and nitrate leaching risk. Nutr Cycl Agroecosys 82:233-249

6. Stein-Bachinger K, Bachinger J, Schmitt L (2004) Naehrstoff-Management im oekologischen Landbau. In: KTBL, Darmstadt (Ed.), Ein Handbuch fuer Beratung und Praxis. Landwirtschaftsverlag Muenster, Muenster, pp 109-114

7. Möller K, Stinner W (2009) Effects of different manuring systems with and without biogas digestion on soil mineral nitrogen content and on gaseous nitrogen losses (ammonia, nitrous oxides). Europ J Agron 30:1-16

8. Körschens M (1987) N-Ausnutzung in Abhängigkeit von mineralischer und organischer N-Düngung im Verlaufe von vier Jahrzehnten im statischen Düngungsversuch Lauchstädt. Archiv. Acker Pflanzenbau Bodenkunde 31:161-168

9. Hauggaard-Nielsen H, Johansen A, Carter MS, Ambus P, Jensen ES (2013) Annual maize and perennial grass-clover strip cropping for increased resource use efficiency and productivity using organic farming practice as a model. Eur J Agron 47:55-64

10. Nemecek T, Kägi T (eds) (2007) Life Cycle Inventories of Agricultural Production Systems; Ecoinvent report No. 15, Agroscope Reckenholz Tänikon Research Station ART, Zürich and Dübendorf, http://www.upe.poli. br/ cardim/PEC/Ecoinvent\%20LCA/ecoinventReports/15_Agriculture.pdf. Accessed 17 June 2014

11. Database ecoinvent 3 (2014), https://ecoquery.ecoinvent.org/Account/ LogOn?Return Url =\%2 f. Accessed 19 June 2014

12. Nemecek T, Schnetzer J (2011) Methods of assessment of direct field emissions for $\mathrm{LCls}$ of agricultural production systems. Agroscope Reckenholz - Tänikon Research Station ART, Zürich and Dübendorf

13. Stinner W (2011) Auswirkungen der Biogaserzeugung in einem ökologischen Marktfruchtbetrieb auf Ertragsbildung und Umweltparameter; Giessener Schriften zum ökologischen Landbau; Band 4; Verlag Dr. Köster, Berlin

14. Daniel-Gromke J, Liebetrau J, Denysenko V, Krebs C (2014) Digestion of bio-waste - GHG emissions and mitigation potential (accepted for publication in Energy, Sustainability and Society)

15. Huijsmans JFM, Hol JMG, Hendriks MMWB (2001) Effect of application technique, manure characteristics, weather and field conditions on ammonia volatilization from manure applied to grassland. NJAS Wageningen J Life Sci 49(4):323-342

16. Huijsmans JFM, Hol JMG, Vermeulen GD (2003) Effect of application method, manure characteristics, weather and field conditions on ammonia volatilization from manure applied to arable land. Atmos Environ 37(26):3669-3680

17. Kirchmann H, Witter E (1989) Ammonia volatilization during aerobic and anaerobic manure decomposition. Plant Soil 115:35-41

18. Bernal MP, Kirchmann H (1992) Carbon and nitrogen mineralization and ammonia volatilization from fresh, aerobically and anaerobically treated pig manure during incubation with soil. Biol Fertil Soils 13(3):135-141
19. Bussink DW, Oenema O (1998) Ammonia volatilization from dairy farming systems in temperate areas: a review. Nutr Cycl Agroecosyst 51:19-33

20. Huijsmans JFM, de Mol RM (1999) A model for ammonia volatilization after surface application and subsequent incorporation of manure on arable land. J Agric Eng Res 74(1):73-82

21. Fageria NK, Baligar VC (2005) Enhancing nitrogen use efficiency in crop plants. Adv Agron 88:97-185

22. Pierce FJ, Rice CW (1988) Crop rotation and its impact on efficiency of water and nitrogen use. In: Ellis BG, Hargrove WL (eds) Cropping strategies for efficient use of water and nitrogen, vol 51. ASA Special Publications, American Society of Agronomy, pp 21-42

23. Dawson JC, Huggins DR (2008) Jones SS (2008) Characterizing nitrogen use efficiency in natural and agricultural ecosystems to improve the performance of cereal crops in low-input and organic agricultural systems. Field Crop Res 107:89-101, Review

24. Edmeades DC (2003) The long-term effects of manures and fertilisers on soil productivity and quality: a review. Nutr Cycl Agroecosyst 66:165-180

25. Smith KA, Chambers BJ (1993) Utilizing the nitrogen content of organic manures - on-farms-problems and practical solutions. Soil Use Manag 9:3

26. Richards JE, Soper RJ (1979) Effect of N fertilizer on yield, protein content, and symbiotic N fixation in faba beans. Agron J 71:807-811

27. VDLUFA, Hrsg, (2014) Standpunkt; Humusbilanzierung - Eine Methode zur Analyse und Bewertung der Humusversorgung von Ackerland; Verband Deutscher Landwirtschaftlicher Untersuchungs- und Forschungsanstalten; available: http://www.vdlufa.de/index.php?option=com_content\&view= article\&id=21\&ltemid $=37$ (30.12.2014)

28. Brozyna MA, Petersen SO, Chirinda N, Olesen JE (2013) Effects of grassclover management and cover crops on nitrogen cycling and nitrous oxide emissions in a stockless organic crop rotation. Agr Ecosyst Environ 181:115-126

29. Jensen ES (1987) Seasonal patterns of growth and nitrogen fixation in field-grown pea. Plant Soil 101:29-37

30. Hansen JP, Vinther FP (2001) Spatial variability of symbiotic $\mathrm{N}_{2}$ fixation in grass-white clover pastures estimated by the $15 \mathrm{~N}$ isotope dilution method and the natural $15 \mathrm{~N}$ abundance method. Plant Soil 230:257-266

31. Hardarson G, Atkins C (2003) Optimizing biological $N_{2}$ fixation by legumes in farming systems. Plant Soil 252:41-54

32. Høgh-Jensen H, Schjørring JK (1997) Interactions between white clover and ryegrass under contrasting nitrogen availability: $\mathrm{N}_{2}$ fixation, $\mathrm{N}$ fertilizer recovery, N transfer and water use efficiency. Plant Soil 197(2):187-199

33. Rossato L, Lainé $P$, Ourry A (2001) Nitrogen storage and remobilization in Brassica napus L. during the growth cycle: nitrogen fluxes within the plant and changes in soluble protein patterns. J Exp Bot 52(361):1655-1663

34. Deuker A, Stinner W, Leithold G (2008) Biogas energy potentials from agricultural by-products: examples from organic farming in Germany compared with energy corn. In: Abstracts of the 16th European Biomass Conference and Exhibition - From Research to Industry and Markets, Valencia, Spain, 2-6 June 2008; ETA-Florence Renewable Energies, Florence (ed.)

35. FNR (2011) Standortangepasste Anbausysteme für Energiepflanzen. Gülzow, Germany, http://mediathek.fnr.de/media/downloadable/files/samples/f/g/ fg_broschur_energiepfl_eva_2011_v2.pdf. Accessed 17 June 2014

36. Hummel HE, Deuker A, Leithold G (2009) The leaf beetle Diabrotica virgifera virgifera LeConte: a merciless entomological challenge for agriculture. In: Tasin M, Witzgal P (eds) IOBC-WPRS Bulletin, vol 41, p 103-110

37. Deuker A, Stinner W, Rensberg N, Wagner L, Hummel HE (2012) Regional risks for the biogas production in Germany by the maize pest Diabrotica $\mathrm{V}$. virgifera. J Agr Sci Tech 2:749-767

38. Deuker A (2013) Energieerzeugung in landwirtschaftlichen Biogasanlagen: Potenziale und Grenzen. Verlag Dr. Köster, Berlin

39. Kramberger B, Gselman A, Kristl J, Lešnik $M$, Šuštar V, Muršec M, Podvršnik $M$ (2014) Winter cover crop: the effects of grass-clover mixture proportion and biomass management on maize and the apparent residual $\mathrm{N}$ in the soil. Eur J Agron 55:63-71

40. Frøseth RG, Bakken AK, Bleken MA, Riley H, Pommeresche R, ThorupKristensen K, Hansen S (2014) Effects of green manure herbage management and its digestate from biogas production on barley yield, $\mathrm{N}$ recovery, soil structure and earthworm populations. Eur J Agron 52:90-102

41. Boehmel C, Lewandowski I, Claupein W (2008) Comparing annual and perennial energy cropping systems with different management intensities. Agric Syst 96(1):224-236 
42. Launder K (2002) Energy crops and their potential development in Michigan; Michigan Biomass Energy Program, August, 2002; Michigan Department of Consumer and Industry Services, Energy Office (ed)

43. Keymer U (2014): Biogasausbeuten verschiedener Substrate; available under http://www.ff.bayern.de/iba/energie/049711/ (01.12.2014)

Submit your manuscript to a SpringerOpen ${ }^{\odot}$ journal and benefit from:

- Convenient online submission

$\checkmark$ Rigorous peer review

- Immediate publication on acceptance

- Open access: articles freely available online

- High visibility within the field

- Retaining the copyright to your article

Submit your next manuscript at $\mathbf{s p r i n g e r o p e n . c o m ~}$ 